\title{
Total Economic Value of Applied Used Green Line Street Model For Tamarindus Indica in Rembang District
}

\author{
Abdillah Rangga Fajar ${ }^{1, *}$, Bambang Azis Nur ${ }^{2}$ \\ ${ }^{1}$ Master Program of Environmental Science, School of Postgraduate Studies, Diponegoro University, Semarang-Indonesia \\ ${ }^{2}$ Faculty of Fisheries and Marine Science, Diponegoro University, Semarang - Indonesia
}

\begin{abstract}
One of the green line street functions is to providing land of carbon sink crops. Javanese tamarind (Tamarindus indica) is a type of productive crop that has a carbon absorbent function. The type of Javanese tamarind crops production is wood products and tamarind fruit harvest products. The purpose of this study to determine the total economic value (NET) a calculation of the model of the applied use of green line street for Javanese tamarind plants. The economic value that can be calculated from the modeling are Direct Value and Indirect Value. Direct benefit value consist of value of wood and value of crop. While indirect benefits value consist of value of carbon stock and biodiversity value. This research was conducted in May 2017 in Rembang District, Rembang Regency, Central Java. The methods used are allometric modeling method and economic valuation method. Allometric modeling method is used to determine the potential of carbon and wood reserves along the green line street. While the economic valuation method is used to calculate total economic value of the application of this modeling result. Applying of this model has result in total economic value Rp 1,942,788,721 per year. It can be concluded that the green liner street has great potential utilization and should be optimally utilized.
\end{abstract}

\section{Introducing}

The existence of Green Open Space is required by a city or region. One of the green open space forms in a city is urban forest. The urban forest is divided into the following classifications; green line, garden city, gardens and courtyards, botanical gardens, forest and zoos, protected forests, cemetery and heroes parks [1].

At this time Green Open Space public areas of Rembang City area provide $73.10 \mathrm{Ha}$ or only $2.3 \%$ is calculated from the total area of Rembang City ( 31183.76 ha), the number still far from the minimum requirements. According to Minister of Public Works Regulation no. 05 of 2008 requires that the green open space public urban area must be fulfilled at least $20 \%$ of the total area of the city [2]. Increased green open space is necessary, one of them is to optimize the potential of the green line street.

The green line street that constitutes the urban forest certainly has a very important role for city. Long-lived plants or trees grown in forests as well as in mixed gardens are places where carbon stocking or storage is much larger than in annual crops. Therefore, long-lived tree species are the highest $\mathrm{C}$ storage warehouse capable of reducing the greenhouse gas effect [3].

How important the green line street in a city can be measured its economic value, either from environmental services or from direct use of resources on the green line street. To find out the economic value is required a model to calculating the utilization of green line street with productive plants, like Javanese Tamarind. Javanese Tamarind or Tamarindus Indica in Latin name was chosen because the existing location of research has been found. In addition Javanese Tamarind have the potential of ecology as a carbon sink and has the economic potential of wood and fruit produced. Besides this Javanese Tamarind does not require special treatment throughout the season so it does not require treatment costs.

\section{Research Method}

\subsection{Time and Place of Research}

This research was conducted by modeling the calculation of district roads in Rembang, Rembang, Central Java, which was implemented in June 2017.

\subsection{Variable Measurement Concept}

Variable measured in this research are

a. The green open space area of green line street can be utilized as planting land of Javanese Tamarind.

b. The direct benefits value from resulting the direct utilization of green open space green roads such as: timber potential and fruit potential of Java Acid ( $\mathrm{Rp}$ / year) 
c. The indirect benefits value from resulting indirect utilization of green open space green roads such as; Economic value of carbon exchange ( $\mathrm{Rp} /$ year).

d. Cost. Cost incurred by the beneficiaries of the green open space on the green line street to get the commodity from the green road area $(\mathrm{Rp} /$ year)

\subsection{Collecting Data Method}

\subsubsection{The Length of road}

The length of the road calculated in this study is the entire length of the road belonging to the district in the District of Rembang. This data is obtained through the Decree of the Rembang Regent No. 900/893/2017 on the Stipulation of Roads of District and Poros of Village in Rembang Regency.

\subsubsection{Javanese Tamarind Crop}

This study is a simulation of calculation of a planting model, then data about tree height, tree circumference, and fruit harvest quantity using previous research results to obtain uniform data. So it is easier in the process of calculating the simulation results.

\subsection{Processing Method and Data Analysis}

\subsubsection{Green Line Street Analysis}

The area of the green line street is obtained from the area of each road, then the total number of all existing road segments.

\subsubsection{Standing Volume Wood Analysis}

Analysis of standing volume to find out the volume of existing mangrove wood. To obtain the volume of wood, it must first be known the value of the height and also the circumference of the circle as high as the chest (1.3 $\mathrm{m})$ tree planned in the modeling. The data obtained are included in Table 1.

Table. 1. Diameter and Height of Wood Planned

\begin{tabular}{|c|l|l|l|l|}
\hline No & Tree Type & Diameter & Height & $\begin{array}{l}\text { Volume } \\
\left(\mathbf{m}^{\mathbf{3}}\right)\end{array}$ \\
\hline 1 & $\begin{array}{l}\text { Javanese } \\
\text { Tamarind }\end{array}$ & & $\mathbf{( m )}$ & \\
\hline
\end{tabular}

source : researcher, 2017

The volume of this wood is obtained by using equation [4]:

That:

$$
\mathrm{V}=(\operatorname{Lbd} \mathrm{xt})
$$

$\mathrm{V}=$ Volume

Lbd $=$ Broad base area $\left\{[(\text { diameter } / 100) \times 0.5]^{2}\right\}$ $\mathrm{x} \Pi$

$$
\mathrm{T} \quad=\text { height }(\mathrm{m})
$$

The analysis of standing volume will illustrate the condition of the green line street of the road on each hectare. It can also be used as the initial calculation of the potential economic value of Javanese Tamarind wood.

The stand value can be determined by calculating the resulting cubic timber multiplied by the selling price per $\mathrm{m}^{3}$ multiplied by the green line street area.

\subsubsection{Biomass and Carbon Stock Analysis}

In calculating the amount of carbon it uses allometric equations for trees because Java Acid is included in the category of hard trees. Allometri used to measure the hard tree as follows [5]

$$
\mathrm{B}=\mathrm{a} \mathrm{DBH}^{\mathrm{b}}
$$

That :

$$
\begin{array}{ll}
\mathrm{B} & =\text { Biomass (ton) } \\
\mathrm{a} \text { and } \mathrm{b} & =\text { Constanta } \\
\mathrm{DBH} & =\text { Diameter at Breast Height }
\end{array}
$$

Constant values for hard trees are as follows:

$$
\mathrm{a}=0,133 \text { and } \mathrm{b}=1,164 \text {. }
$$

The amount of Biomass is the amount of the biomass of the trees. To know the total amount of biomass then it must be multiplied by the number of trees that exist. Modeling the number of trees on the green line street of the road can be seen in the following table:

Table. 2. Tree Planting Distance Planned

\begin{tabular}{|l|c|c|l|l|}
\hline No & $\begin{array}{c}\text { Total of } \\
\text { Length } \\
\text { Road } \\
\text { (m) }\end{array}$ & $\begin{array}{c}\text { Distance } \\
\text { Planting } \\
\text { (m) }\end{array}$ & $\begin{array}{l}\text { Amount } \\
\text { of } \\
\text { Side } \\
\text { Planting }\end{array}$ & $\begin{array}{l}\text { Amount } \\
\text { of tress }\end{array}$ \\
\hline 1 & & & & \\
\hline
\end{tabular}

Carbon stocks are estimated by multiplying the value of tree biomass with a conversion value of $50 \%$ that roughly $50 \%$ of the tropical wood biomass content is composed of carbon [6]

$$
\text { Carbon }(C)=\mathrm{Y} \times 0.5
$$

That $\mathrm{C}=$ Carbon $(\mathrm{kg})$, and $\mathrm{Y}=$ Biomass $(\mathrm{kg})$.

\subsection{Green Line Street Economical Valuation}

The assessment of green line street economical valuation done by using two stages of approach: the stage of identification of benefits and functions of existing resources, then proceed with the phase of 
calculation all benefits and functions into the value of money.

\subsubsection{Identify the benefits and functions of the green line street resource}

The economic value of a greenline street resource is divided into two, namely direct and indirect values

a. direct use value

The value of direct benefits is the value that results from the direct utilization of a resource. Direct benefits can mean the benefits that can be consumed. The direct benefit value of this green line is calculated by the following equation [7]:

$$
\mathrm{DUV}=\Sigma \mathrm{DUVi}
$$

That:

DUV $=$ Direct use value

DUV 1 = wood benefit

DUV 2 = fruit benefit

\section{b. Indirect use value}

Indirect benefits are the value of the benefits of an indirectly utilized green line resource. The indirect benefits of a green line street are carbon sinks. This benefit can be calculated through a carbon exchange mechanism.

\subsubsection{Quantify all benefits and functions into the value of money.}

Once all the benefits are identified, the next step is to quantify all the benefits into the value of money with several values:

a. Market value

This market value approach is used to calculate the economic value of commodities that can be directly utilized from the pathway green resources.

b. Indirect Price

This approach is used to assess the indirect benefits of planned road green paths, such as the value of carbon exchanges

c. Total Economic Benefit Value The total useful value of a green open space area in the form of a green pathway is the sum of all economic values of the green line benefits identified and quantified into the value of money. The total benefit value is calculated using the following equation [7] with the modification of the researcher:

$$
\mathrm{TEV}=\mathrm{DUV}+\mathrm{IUV}
$$

TEV = Total Economic Value

DUV $=$ Direct Use Value

IUV = Indirect Use Value

\section{Result And Discussion}

\subsection{Regional General Condition}

Rembang Regency is located in Rembang District, Central Java Province, Indonesia. Border area of Kec. Rembang as follows:

- North side $=$ Java Sea

- East side = Lasem sub-district

- South side = Sulang sub-district

- West side = Kaliori sub-district

Based on data from the Regional Government of Rembang Regency, the area of Rembang District 5,881 Ha with District road length of $77.9 \mathrm{Km}$.

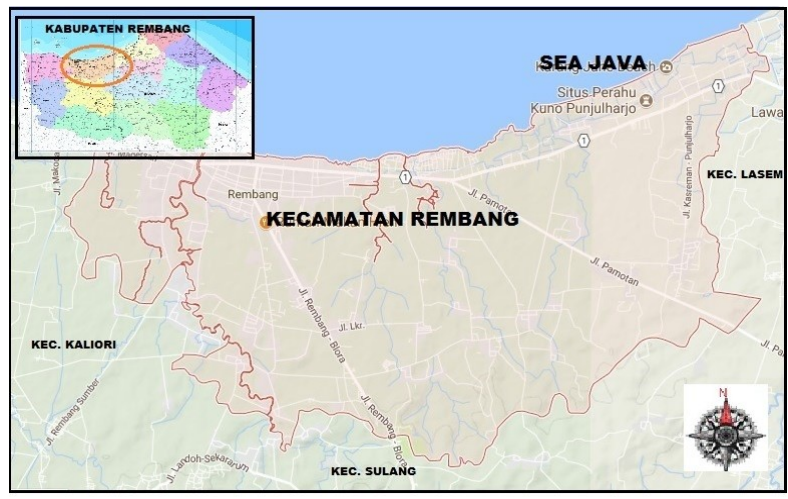

Fig. 1. Rembang District Map

\subsection{Modeling Description}

This modeling is a simulation of the potential calculation of the planting of Java Acid on the green path of the road in the District of Rembang. The focus of this research is only on the simulation result of the calculation only. So that the existing plant conditions on the path of this green road is not included. This effort is done to make it easier to get the calculation of potential planting. The simulation step is as follows:

a. Determining the total area of road in the district of Rembang. This total area is considered a broad green pathway. Through direct observation at the location where there is a Javanese Acid plant, this Java Acidic canopy cover covers almost the entire area under it. As shown in the picture below.

b. Determine the desired dimension of tree dimension (tree age, tree trunk circumference and number of fruit harvest) using previous research results.

c. Calculate the potential benefits of applying the planting model. 


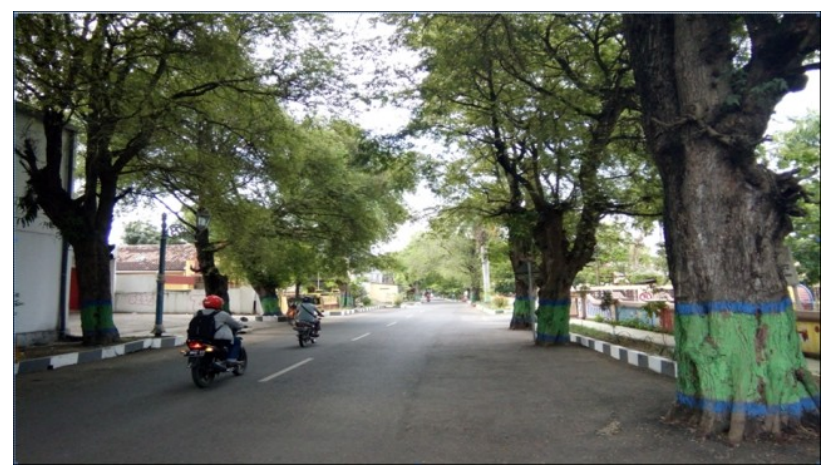

Fig. 2. The Javanese Tamarind plant head covering the area of the road

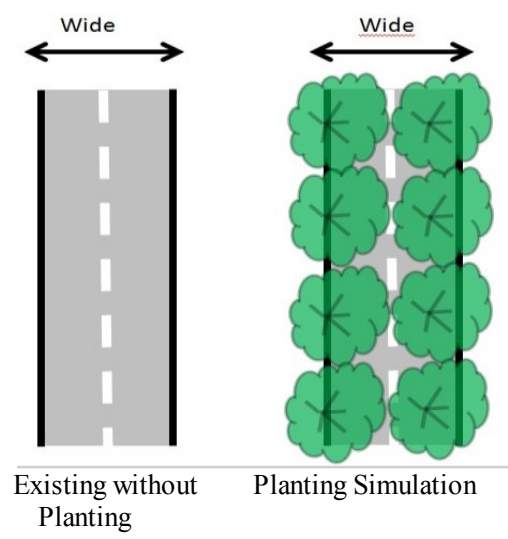

Fig. 3. Planting Apply Ilustration

\subsection{Total of Green Line Street Land}

Table 3. Area Roads District in District Rembang

\begin{tabular}{|c|c|c|c|}
\hline No & Road Size Name & $\begin{array}{c}\text { Lenght } \\
\text { (m) }\end{array}$ & $\begin{array}{c}\text { Width } \\
\text { (m) }\end{array}$ \\
\hline 1. & Sumberjo & 6100 & 4 \\
\hline 2. & - Kebonagung & 2700 & 3.5 \\
\hline 3. & - Pranti & 2000 & 3 \\
\hline 4. & - Nganguk & 2400 & 4 \\
\hline 5. & - Nganguk & 2500 & 3 \\
\hline 6. & Bagel & 1600 & 3 \\
\hline 7. & Pasar Pentungan - Pulo & 2700 & 7 \\
\hline 8. & Pasar Pentungan - Pulo & 3400 & 7 \\
\hline 9. & Sumberjo $\quad$ - Pulo & 2100 & 4 \\
\hline 10. & Jl. KS. Tubun & 900 & 4 \\
\hline 11. & Jl. Sumberejo & 1000 & 4 \\
\hline 12. & J1. Sidodadi & 300 & 4 \\
\hline & Jl. M. Yamin & 400 & 4 \\
\hline & Jl. Yos Sudarso (ex Jl. Kp. Baru) & 1000 & 7 \\
\hline 15. & Jl. Achmad Yani (ex Jl. Sawahan) & 1300 & 4 \\
\hline 16. & Jl. Achmad Yani (ex Jl. Grajen) & 500 & 3 \\
\hline 17. & Jl. Palen & 400 & 3 \\
\hline 18. & Jl. Kulit & 400 & 3 \\
\hline 19. & Jl. Erlangga & 500 & 3 \\
\hline 20. & Jl MH. Tamrin & 500 & 3 \\
\hline 21. & J1 Dampo Awang & 300 & 4 \\
\hline 22. & Jl. R. Shaleh & 300 & 4 \\
\hline 23. & Jl. Dr. Wahidin & 1100 & 8 \\
\hline 24. & Jl. Lumba- lumba & 1400 & 4 \\
\hline & Jl. Dorang & 900 & 4 \\
\hline
\end{tabular}

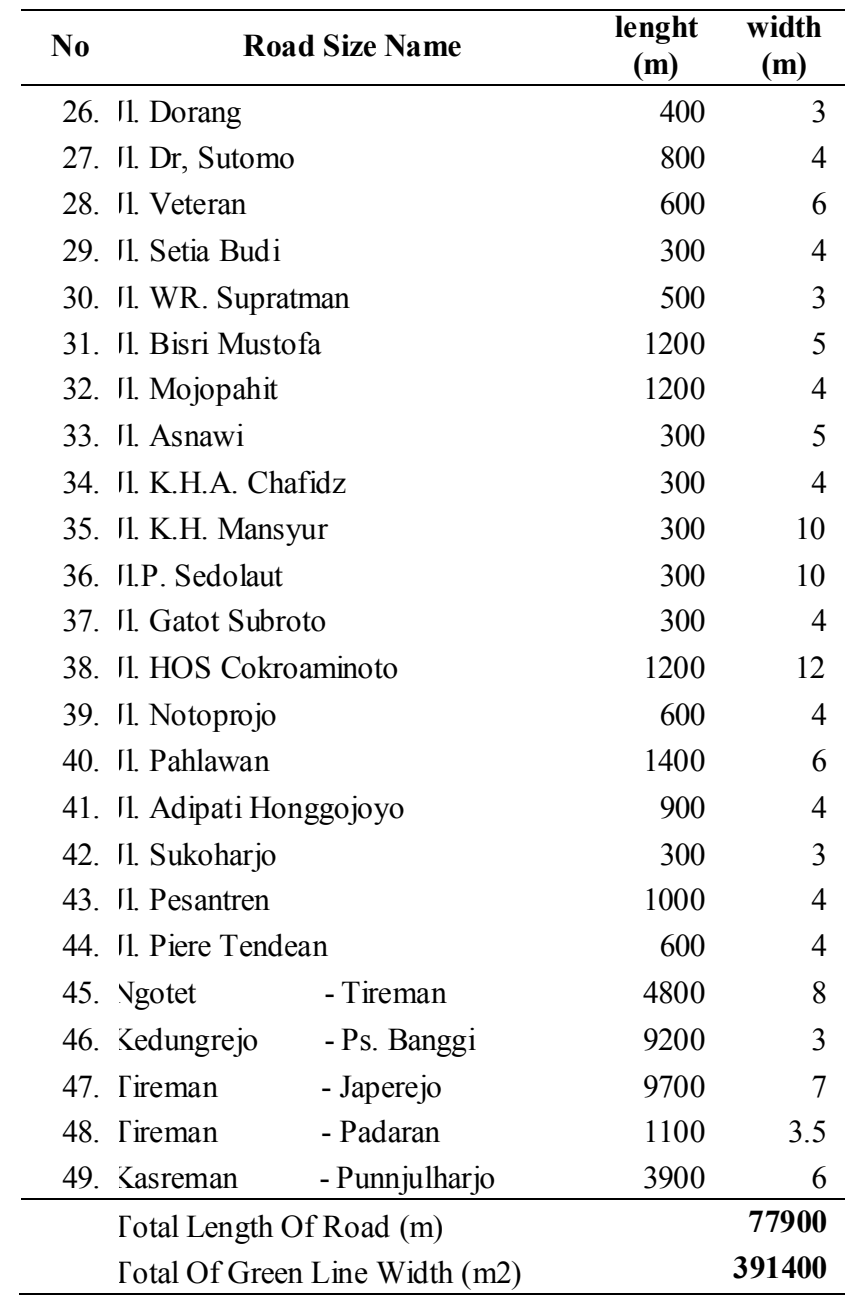

By using the data length and road width, the total area of green path is $391400 \mathrm{~m}^{2}$ or $39.1 \mathrm{Ha}$. 


\subsection{Direct Use Potential Analysis}

\subsubsection{Economical of Javanese Tamarind Wood Potential}

Analysis of standing volume is used to determine the volume that Java Acid wood can produce in each hectare. This data is used to find the value of the direct benefits of the green road path of potential timber that can be produced.

At adult tree age about 50 years diameter $1.6 \mathrm{~m}$ logs and also high tree acid $25 \mathrm{~m}$ Java [8], obtained the potential volume of Java acid volume Of $70.84 \mathrm{~m} 3$ per ha as shown in the Table 4.

Table 4. Calculation of Wood Volume Per Hectare

\begin{tabular}{|l|l|c|c|c|}
\hline No & Tree Type & $\begin{array}{l}\text { Diameter } \\
(\mathbf{c m})\end{array}$ & $\begin{array}{l}\text { Height } \\
(\mathbf{m})\end{array}$ & $\begin{array}{l}\text { Volume } \\
\left(\mathbf{m}^{\mathbf{3}}\right)\end{array}$ \\
\hline 1 & $\begin{array}{l}\text { Javanese } \\
\text { Tamarind }\end{array}$ & 160 & 25 & 70,84 \\
\hline
\end{tabular}

Source : Processed data, 2017

The total area of the green road is $39.1 \mathrm{Ha}$. So the volume of Java Acid wood as a whole is $2773 \mathrm{~m} 3$. Based on data from Perum Perhutani in 2016, Java Asam wood entered in the second type of wood forest usage, that is for non-structural purposes. The price of Java Acid wood in this class is $\mathrm{Rp} 2,225,000$ per $\mathrm{m} 3$ [9], so the potential economic value of Java Asam wood on the green line is Rp 6.169.925.000, -. If it is assumed to be a cutting cycle for 50 years, then the benefits of production earned amount to $\mathrm{Rp} 123,398,500$, - per year.

\subsubsection{Economic Potential of Javanese Tamarind Fruit}

The potential of Javanese fruit harvest is as big as 0.82 tons per hectare per year [10], so the number of potential harvests on the road green path with an area of 39.1 ha is 32 tons or $32,000 \mathrm{~kg}$ per year. While the current market price of this research is done in the year 2017 is worth Rp 10.000, - per kilo. Thus, the economic value of Javanese Acid fruit in planting model on the green road is $\operatorname{Rp} 320,000,000$ per year

\subsection{Indirect Use Potential Analysis}

\subsubsection{Economic Potential of Carbon Stock}

To calculate the value of carbon stock, it is necessary to find the amount of carbon uptake or biomass at that location. Using allometric equation for plant species in tropical forest, the biomass value as shown in the following Table shows.
Table 5. Result of Measuring Biomassa value/ tree

\begin{tabular}{|c|c|c|c|c|c|}
\hline No & $\begin{array}{c}\text { Tree } \\
\text { Type }\end{array}$ & $\begin{array}{c}\text { constanta } \\
\text { (a) }\end{array}$ & $\begin{array}{c}\text { constanta } \\
\text { (b) }\end{array}$ & $\begin{array}{c}\text { DBH } \\
\text { (cm) }\end{array}$ & $\begin{array}{c}\text { Biomassa } \\
\text { (ton) }\end{array}$ \\
\hline & $\begin{array}{c}\text { Javanes } \\
\mathrm{e} \\
\text { Tamari } \\
\text { nd }\end{array}$ & 0,133 & 1,164 & 160 & 48,9 \\
\hline
\end{tabular}

Source: Processed data, 2017

After the amount of biomass in each tree is found then multiplied by the number of trees that can be planted in this model. The number of trees can be seen in the following

Table 6. Result of Measuring Amount Plan Trees

\begin{tabular}{|c|l|c|l|l|}
\hline No & $\begin{array}{l}\text { Total } \\
\text { Length } \\
\text { Road (m) }\end{array}$ & $\begin{array}{l}\text { Distance } \\
\text { Planting } \\
\text { (m) }\end{array}$ & $\begin{array}{l}\text { Amount } \\
\text { of } \\
\text { Side } \\
\text { Planting }\end{array}$ & $\begin{array}{l}\text { Amount } \\
\text { of tree }\end{array}$ \\
\hline 1 & 77900 & 10 & 2 & 15.580 \\
\hline
\end{tabular}

In this calculation obtained biomass value of 761,862 Ton. The value of carbon stocks stored in the biomass is 380,931 Ton, or $50 \%$ of the existing nico biomass [6].

The economic value of stored carbon stocks can be calculated by carbon trading schemes. The economic value of carbon stock or carbon price varies according to various sources. According to Saloh and Clough states that carbon prices in carbon trading are US \$ 15 - 20 US $\$$ per ton of carbon absorbed [10]. In this calculation take the lowest price of US $\$ 15$ per ton of carbon absorbed. So the economic value of carbon stocks on the

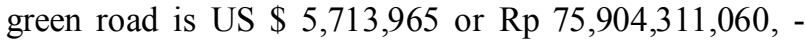
(The rupiah exchange rate at the time of this research is Rp 13,284$)$. This benefit is obtained within 50 years of planting time, so the economic value of carbon stock is Rp 1,518,086,221 per year.

\subsection{Price Proceed Analysis}

In the cultivation of Javanese Acid this is actually no significant management costs because it does not require watering and hold during the dry season [8]. So the cost that appears in this modeling is the cost of procurement of seeds of Java Acid for this green path of 15,580 seeds. Based on the market price at the time of the research, the price of seeds of Java Acid Rp 50.000, - and the cost of planting is assumed Rp 10.000, - per seedlings. So the total cost for this road green road modeling is $\mathrm{Rp}$ $934,800,000,-$. The fee is for the value of the investment utilization for 50 years. So the average cost incurred in the application of this model is $\mathrm{Rp} 18,696,000$ per year. 


\subsection{Total Economic Value}

The total economic value of the utilization of the green road path can be seen in the following table

Table 7. Green Line Street Total Economic Value

\begin{tabular}{|c|l|c|r|}
\hline No & \multicolumn{1}{|c|}{ Benefit Type } & Type & Value (Rp/year) \\
\hline \multirow{2}{*}{1} & \multirow{2}{*}{ Direct use value } & wood & 123.398 .500 \\
\cline { 3 - 4 } 2 & fruit & 320.000 .000 \\
\hline 3 & Indirect use value & $\begin{array}{l}\text { Carbon } \\
\text { Stock }\end{array}$ & 1.518 .086 .221 \\
\hline \multicolumn{2}{|l|}{ Total economic value } & & -18.696 .000 \\
\hline
\end{tabular}

Source : Processed data, 2017

\section{Conclusions and Suggestion}

\subsection{Conclusion}

Based on the result, the total economic value of green road utilization is $\mathrm{Rp} 1,942,788,721$ per year, calculated from direct benefit ( $R p$ 323,398,500 per year), indirect benefit (Rp 1,518,086,221 per year) and reduced by cost (Rp 18,696,000 per year)

\subsection{Suggestion}

Seeing the huge economic value of the results of Java Acid planting modeling on the green road in Rembang District, should the government and the community cooperate in realizing the modeling of this planting. Besides beneficial from the ecological side of the application of Java Asam planting is also beneficial from the economic side.

\section{References}

1. Dahlan, N.E,.Hutan Kota untuk Pengelolaan dan Peningkatan Kualitas Lingkungan Hidup. Asosiasi Pengusahan Hutan Indonesia. Jakarta. ( 1992)

2. Mashuri et al. Jurnal Teknik Sipil dan Perencanaan, Vol 14, Semarang (2012)

3. K. Hairiah, and S. Rahayu, Pengukuran Karbon Tersimpan di Berbagai Macam Penggunaan Lahan. ICRAF. Bogor, (2007)

4. Santoso. Valuasi Ekonomi Ekosistem Hutan Mangrove di Kawasan Pondok Bali, Desa Legonwetan, Kecamatan Legonkulon, Kabupaten Subang, Jawa Barat. Bogor. Institut Pertanian Bogor, (2005)

5. N. S. Dudley and J. H. Fownes Journal of Tropical Forest Science Vol. 5, No. 1 (September 1992), pp. 68-73

6. S. Brown, Estimasi Biomass and Biomass Change Of Tropical Forest. FAO forestry Paper. Roma, (1997)

7. Bishop, J.T. (ed.), Valuing Forests: A Review of Methods and Applications in Developing Countries. International Institute for Environment and Development: London, (1999)

8. R. Rukmana, "Budidaya Asam Jawa." Kanisius, Yogyakarta (2005).

9. Surat Direksi Perum Perhutani Nomor:, Tahun 2016

10. Tree Corp Estate of Indonesia, Spices and Beverage Crops. Ministry of Agriculture Repiblic of Indonesia Directorate General o Estate Crops. (2014) 